\title{
Sekolah Sahabat Gawai: Pendampingan Kegiatan Belajar dari Rumah untuk Menjaga Kesehatan Siswa SMP Islam Dian Didaktika
}

\author{
Nurfitri Bustamam ${ }^{1}$, Duma Lumban Tobing ${ }^{2}$, Evin Novianti ${ }^{2}$ \\ 1. Fakultas Kedokteran Universitas Pembangunan Nasional Veteran Jakarta \\ 2. Fakultas IImu Kesehatan Universitas Pembangunan Nasional Veteran Jakarta \\ email: nurfitri.bustamam@upnvj.ac.id
}

\begin{abstract}
Abstrak
Pada Tahun Akademik 2020/2021 pembelajaran secara tatap muka bagi siswa sekolah di sebagian besar wilayah Indonesia dilarang untuk mencegah penularan coronavirus disease (COVID)19. Sebagai gantinya dilaksanakan pembelajaran dari rumah (BDR). Akibatnya penggunaan gawai oleh siswa sekolah meningkat tidak hanya untuk kegiatan pembelajaran, tetapi juga sebagai sarana komunikasi, hiburan/rekreasi, dan bersosialisasi. Penggunaan gawai yang berlebihan akan meningkatkan risiko timbulnya masalah kesehatan baik fisik maupun mental. Berdasarkan hal tersebut, pihak sekolah bekerjasama dengan tim pengabdi dari Fakultas Kedokteran dan Fakultas Ilmu Kesehatan Universitas Pembangunan Nasional Veteran Jakarta melakukan kegiatan pengabdian kepada masyarakat (PKM) dengan tema "Sekolah Sahabat Gawai." Kegiatan PKM ini bertujuan untuk: 1) Meningkatkan pengetahuan siswa tentang masalah kesehatan baik fisik maupun mental akibat penggunaan gawai berlebihan dan 2) Siswa mengimplementasikan upaya untuk mencegah/mengurangi risiko masalah kesehatan selama menggunakan gawai. Mitra kegiatan PKM ini adalah Siswa SMP Dian Didaktika kelas 8 dan 9. Edukasi kepada siswa oleh tim pengabdi dilakukan dari studio sekolah menggunakan google meet. Sebelum dan sesudah edukasi, siswa diberikan pre dan post-test untuk mengukur tingkat pengetahuan. Seminggu kemudian siswa diminta mengisi daftar tilik terkait aktivitasnya menggunakan gawai. Guru sekolah juga dimintai pendapatnya berkaitan dengan PKM. Hasil dari PKM ini adalah peningkatan pengetahuan siswa terkait penggunaan gawai dan sebagian besar siswa telah melakukan upaya agar tetap sehat pada saat menggunakan gawai selama BDR. Guru sekolah berpendapat bahwa kegiatan PKM ini merupakan bekal bagi siswa untuk dapat menggunakan gawai dengan bijak sehingga tetap sehat selama BDR.
\end{abstract}

Kata kunci: Belajar dari Rumah, COVID-19, Edukasi, Gawai, Masalah Kesehatan

\section{Abstract}

In the Academic Year 2020/2021 learning face-to-face for school students in most parts of Indonesia is prohibited to prevent the spread of coronavirus disease (COVID)-19. Instead, a school from home (SFH) is implemented. As a result, the use of gadgets by school students increases not only for learning activities, but also for communication, entertainment/recreation, and socializing. Excessive use of the gadget will increase the risk of developing health problems both physically and mentally. Based on this, the school collaborated with a team from the Faculty of Medicine and the Faculty of Health Sciences Universitas Pembangunan Nasional Veteran Jakarta to carry out community service activities with the theme "School of Gadget-Friendly." This activity aimed to 1) Increase students' knowledge of health problems both physically and mentally due to excessive use of gadgets and 2) Students implement efforts to prevent/reduce the risk of health problems when they are using gadgets. Partners of this activity were students of Islamic Junior High School Dian Didaktika grades 8 and 9 . Education to students by the team was carried out from the school studio http://ejournal.urindo.ac.id/index.php/PAMAS

Article History : 
using google meet. Before and after education, students were given a pre $\&$ post-test to measure the level of knowledge. A week later the students were asked to fill out a checklist related to their activities using the gadget. School teachers were also asked for their opinions regarding the activity. The results of this activity were an increase in students' knowledge regarding the use of gadgets and most students have made any efforts to stay healthy when using gadgets during SFH. The school teacher argued that this community service activity was a provision for students to be able to use gadgets wisely so that they remained healthy during SFH.

Keywords: COVID-19, Education, Gadget, Health Problem, School from Home

\section{PENDAHULUAN}

Pada saat ini terjadi pandemi coronavirus disease 2019 (COVID-19) yang dengan cepat menyebar dan menyebabkan permasalahan kesehatan serius, bahkan kematian. Pemerintah RI mengeluarkan sejumlah kebijakan untuk mengantisipasi penularan virus tersebut, antara lain melakukan pembatasan sosial berskala besar (PSBB) dengan meliburkan sekolah dan tempat kerja; melakukan pembatasan kegiatan keagamaan dan kegiatan di tempat atau fasilitas umum [1].

Berkaitan dengan pembelajaran, Kementerian Pendidikan dan Kebudayaan (Kemendikbud) melarang kegiatan pembelajaran tatap muka di zona kuning, oranye, dan merah [2]. Sebagai gantinya dilakukan pembelajaran dari rumah (BDR) pada Tahun Akademik 2020/2021. Akibatnya penggunaan gawai baik dalam bentuk laptop, telpon pintar, dan notebook, oleh siswa sekolah meningkat tidak hanya untuk kegiatan pembelajaran, tetapi juga sebagai sarana komunikasi, hiburan/rekreasi, dan bersosialisasi.

Penggunaan gawai yang berlebihan akan meningkatkan risiko timbulnya masalah kesehatan baik fisik maupun mental. Gawai yang terhubung sistem daring (online) ibarat pisau bermata dua, dapat bermanfaat atau membahayakan kehidupan anak. Selain sebagai alat komunikasi dan sumber informasi, gawai yang dilengkapi berbagai fitur juga menjadi pintu masuk bagi anak untuk mengakses media sosial, game, dan fitur lainnya yang tidak sesuai untuk usianya. Bahkan, penggunaan gawai yang terus-menerus tanpa mengenal waktu berpotensi mengganggu tumbuh kembang anak serta membuat anak kecanduan gawai. Penggunaan gawai pada anak yang lebih dari tiga jam dalam sehari dapat menyebabkan mereka rentan kecanduan gawai. Pada saat ini kecanduan game pada gawai mendapat perhatian dunia. Organisasi Kesehatan Dunia (WHO) belum lama ini menyebutkan kecanduan main game sebagai gangguan kesehatan jiwa, yang masuk sebagai gaming disorder [2]. Permasalahan kesehatan akibat penggunaan gawai berlebihan juga mencakup permasalahan pada penglihatan, kuantitas dan kualitas tidur, kesulitan konsentrasi, gangguan perkembangan fisik (obesitas/underweight), perkembangan sosial (kurangnya interaksi 


\section{Jurnal Pelayanan dan Pengabdian Masyarakat (PAMAS)}

dengan orangtua dan saudara), mental (merasa cemas, perilaku agresi, dan kecanduan) dan menurunnya prestasi belajar [3].

Mengingat permasalahan yang dapat ditimbulkan akibat penggunaan gawai pada saat diimplementasikannya kegiatan BDR, pihak sekolah SMP Islam Dian Didaktika memandang perlu adanya penjelasan tentang bahaya penggunaan gawai secara berlebihan kepada siswa, sehingga siswa termotivasi melakukan sejumlah upaya untuk mengurangi risiko masalah kesehatan tersebut. Penjelasan kepada siswa tentang masalah kesehatan akibat penggunaan gawai berlebihan direncanakan oleh pihak sekolah dilaksanakan sebelum kegiatan BDR TA 2020/2021.

Berdasarkan hal tersebut, pihak sekolah bekerjasama dengan tim pengabdi dari Fakultas Kedokteran dan Fakultas IImu Kesehatan Universitas Pembangunan Nasional Veteran Jakarta melakukan kegiatan pengabdian kepada masyarakat (PKM) dengan tema "Sekolah Sahabat Gawai: Pendampingan Kegiatan Belajar dari Rumah untuk Menjaga Kesehatan Siswa SMP Islam Dian Didaktika."

Kegiatan PKM ini bertujuan untuk: 1) meningkatkan pengetahuan siswa tentang masalah kesehatan baik fisik maupun mental akibat penggunaan gawai berlebihan dan 2) siswa dapat mengimplentasikan tips/kiat untuk mencegah/mengurangi risiko masalah kesehatan selama menggunakan gawai. Diharapkan melalui kegiatan PKM ini masalah kesehatan pada siswa baik fisik maupun mental akibat penggunaan gawai dapat dicegah/dikurangi.

\section{METODE}

Mitra kegiatan PKM ini adalah Siswa SMP Dian Didaktika kelas 8 dan 9. Pengabdi berkoordinasi dengan narahubung sekolah melalui WhatsApp berkaitan dengan rencana dan pelaksanaan kegiatan PKM. Setelah mendapatkan ijin dari Kepala Sekolah, pengabdi memberikan flyer kegiatan PKM kepada siswa melalui narahubung sekolah. Penjelasan kepada siswa tentang masalah kesehatan akibat penggunaan gawai berlebihan dilaksanakan sebelum kegiatan BDR TA 2020/2021 dimulai.

Tim pengabdi datang ke Studio Sekolah SMP Dian Didaktika yang terletak di Jl. Rajawali Blok F No. 16 Cinere Estate, Gandul, Kecamatan Cinere, Kota Depok 16512 pada hari Rabu, 15 Juli 2020 pukul 07.30 WIB untuk melakukan persiapan. Kegiatan PKM dimulai pukul 08.00 WIB menggunakan Google Meet.

Rangkaian kegiatan diawali dengan pembukaan oleh Kepala Sekolah. Kemudian siswa diminta mengisi kuesioner pre-test menggunakan google form untuk mengukur tingkat pengetahuan tentang masalah kesehatan akibat penggunaan gawai berlebihan dan cara mencegahnya. Selanjutnya dilakukan edukasi kepada siswa. Pengabdi pertama dengan latar belakang pengetahuan faal tubuh 
memberikan materi tentang: 1) Masalah kesehatan fisik akibat penggunaan gawai berlebihan, antara lain computer vision syndrome, postur tubuh yang bungkuk, sulit tidur, serta nyeri pada leher dan tangan, serta 2) Edukasi tentang postur tubuh yang benar pada saat menggunakan gawai, tips menjaga kesehatan mata selama menggunakan gawai dan pentingnya melakukan aktivitas lain tanpa gawai. Pengabdi kedua dengan latar belakang pendidikan berkaitan dengan kesehatan jiwa memberikan materi tentang karakter remaja dan faktor yang berpengaruh, sejumlah tanda permasalahan kesehatan mental akibat penggunaan sosial media dan game online, mengajak siswa bersama-sama melakukan cek kesehatan mentalnya sendiri, tips meningkatkan imunitas jiwa, serta menghimbau guru/wali murid memantau kegiatan siswa dan menjadi panutan (role model) yang baik. Pengabdi ketiga menjelaskan dan mendemonstrasikan latihan relaksasi otot progresif yang merupakan latihan yang mudah dilakukan dan terbukti manfaatnya untuk menurunkan ketegangan otot, menghilangkan nyeri leher dan punggung, menurunkan tingkat stres dan kecemasan. Selanjutnya pengabdi ketiga mengajak siswa bersama-sama mempraktikan latihan relaksasi otot progresif (Gambar 1).

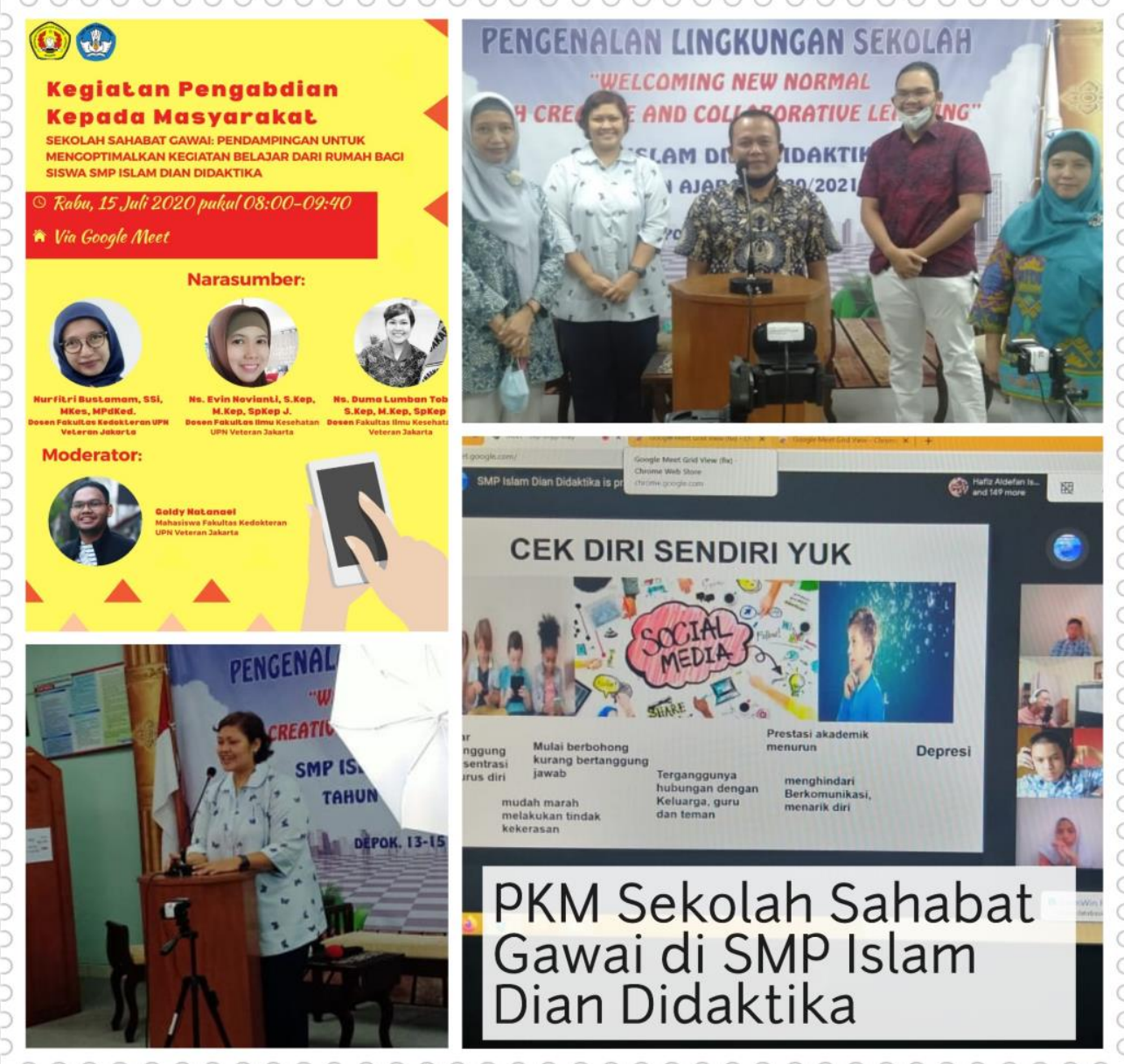

Gambar 1. Flyer PKM, Tim Pengabdi bersama Kepala Sekolah, dan Kegiatan Pengabdi di Studio SMP Islam Dian Didaktika 
Jurnal Pelayanan dan Pengabdian Masyarakat (PAMAS)

Edukasi PKM dilaksanakan menggunakan video dan power point. Pada akhir edukasi diadakan sesi tanya jawab berkaitan dengan materi PKM dibantu oleh mahasiswa Fakultas Kedokteran Universitas Pembangunan Nasional Veteran Jakarta sebagai moderator. Setelah sesi tanya-jawab, siswa diminta mengisi kuesioner post-test yang butir pertanyaannya sama dengan butir pertanyaan pre-test. PKM diakhiri dengan serebrasi bahwa siswa perlu mengimplementasikan tips yang diberikan agar tetap sehat selama belajar dari rumah. Rangkaian kegiatan PKM berakhir pada pukul 10.00 WIB. Seluruh kegiatan direkam oleh pihak sekolah dan materi kegiatan diberikan kepada siswa, guru, dan wali murid agar dapat dipelajari kembali. Diharapkan guru dan wali murid dapat mendampingi kegiatan siswa agar bijak menggunakan gawai.

Seminggu setelah edukasi, siswa diberikan daftar tilik (checklist) tentang aktivitasnya berkaitan dengan penggunaan gawai. Diharapkan pengabdi mendapat gambaran tentang perilaku siswa terkait penggunaan gawai setelah mendapat edukasi.

Evaluasi kegiatan PKM dilakukan oleh pengabdi menggunakan data tingkat pengetahuan siswa sebelum dan setelah PKM, perilaku siswa terkait penggunaan gawai, serta pendapat guru tentang kegiatan PKM secara keseluruhan. Hasil kegiatan PKM diberikan kepada pihak sekolah sebagai umpan balik untuk melakukan upaya tindak lanjut.

\section{HASIL DAN PEMBAHASAN}

Kegiatan PKM dilaksanakan menggunakan google meet dan diikuti oleh siswa SMP Islam Dian Didaktika kelas 8 dan 9, guru, dan wali murid. Total siswa yang mengikuti kegiatan PKM berjumlah 189 orang, laki-laki lebih banyak daripada perempuan, dengan rentang usia antara 13-15 tahun (Tabel 1). Sebelum dan setelah edukasi, siswa diminta untuk mengisi kuesioner berkaitan dengan materi edukasi untuk mengetahui tingkat pengetahuannya.

Tabel 1. Karakteristik Siswa SMP Islam Dian Didaktika

\begin{tabular}{lccc}
\hline Karakteristik & & & \\
\hline 1. Jenis Kelamin & & & \\
& Laki-laki & Perempuan & Total \\
- Kelas 8 & 57 & 43 & 100 \\
- Kelas 9 & 46 & 43 & 89 \\
\hline 2. Usia & & & \\
- 11-12 tahun & 49 & 45 & 94 \\
- 13-15 tahun & 54 & 41 & 95 \\
\hline
\end{tabular}

Berdasarkan hasil analisis didapatkan ada peningkatan median skor pengetahuan dari 4 (2-7) menjadi 6 (3-10). Hasil Uji Wilcoxon menunjukkan ada 3 siswa yang skornya lebih rendah, 74 siswa skornya lebih tinggi dan 14 siswa yang skornya sama setelah mengikuti edukasi. Secara keseluruhan skor pengetahuan lebih tinggi secara signifikan dibandingkan dengan skor sebelum edukasi $(p=$ 
0,000). Hal tersebut menunjukkan bahwa informasi yang disampaikan pada saat edukasi dapat dipahami oleh siswa. Peningkatan pengetahuan ini diharapkan dapat memotivasi siswa untuk melakukan perubahan perilaku sebagai upaya menurunkan risiko timbulnya masalah kesehatan akibat penggunaan gawai berlebihan.

Seminggu setelah edukasi, pengabdi meminta bantuan narahubung untuk memberikan daftar tilik (checklist) kepada sejumlah siswa tentang aktivitasnya berkaitan dengan penggunaan gawai. Perilaku siswa terkait penggunaan siswa dikategorikan menjadi tiga, yaitu: baik (skor 12-18), sedang (skor 7-11), dan kurang (skor 0-6).

Sebanyak 34 dari $51(66,7 \%)$ perilaku siswa dalam melakukan upaya tetap sehat pada saat menggunakan gawai termasuk kategori cukup dan 18 siswa (35\%) termasuk kategori baik (Diagram 1). Ada 2 siswa yang masih kurang berupaya melakukan perilaku sehat terkait penggunaan gawai. Keduanya perlu menjadi perhatian dan didampingi oleh guru/wali murid agar dapat membiasakan diri untuk melakukan perilaku sehat. Perilaku sehat yang perlu dilakukan siswa terkait penggunaan gawai adalah: 1) Mengikuti rumus 20/20/20 pada saat menggunakan gawai, 2) Menjaga jarak antara mata dan komputer minimal $50 \mathrm{~cm}, 3$ ) Duduk tegak menggunakan kursi dan meja saat menggunakan komputer, 4) Membatasi waktu/durasi menggunakan gawai, 5) Menggunakan gawai di ruang yang cukup terang, 6) Mengatur pencahayaan gawai, 7) Tidak menggunakan gawai sebelum tidur, 8) Secara berkala sengaja mengedipkan mata pada saat menggunakan gawai, 9) Melakukan aktivitas lain tanpa gawai yang bermanfaat /menyenangkan, dan 10) Meminta orang tua untuk mendampingi selama menggunakan gawai $[5,6]$.

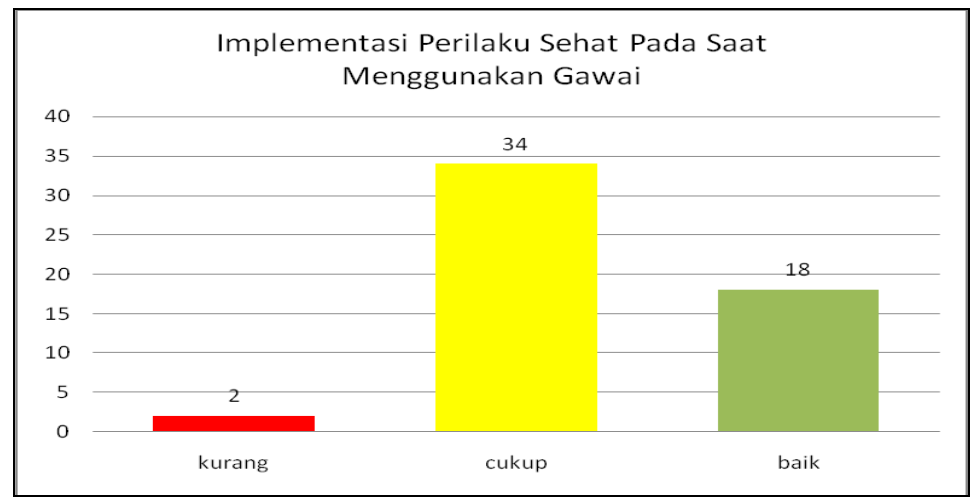

Diagram 1. Gambaran Implementasi Perilaku Sehat oleh Siswa SMP Islam Dian Didaktika

Hasil evaluasi guru SMP Islam Dian Didaktika terkait PKM yang disampaikan oleh narahubung sekolah adalah materi yang disampaikan oleh pengabdi sesuai dengan kebutuhan siswa, karena selama BDR siswa dekat dengan gawai. Siswa telah mendapat pembekalan yang cukup bagaimana menggunakan gawai secara bijak. 
Jurnal Pelayanan dan Pengabdian Masyarakat (PAMAS)

\section{SIMPULAN}

Pelaksanaan PKM di SMP Islam Dian Didaktika dapat meningkatkan pengetahuan dan mengubah perilaku siswa. Sebagian besar $(66,7 \%)$ siswa telah cukup berupaya agar tetap sehat pada saat menggunakan gawai. Hasil evaluasi oleh guru sekolah adalah materi yang disampaikan pengabdi merupakan bekal bagi siswa agar dapat menggunakan gawai dengan bijak sehingga tetap sehat selama BDR.

Berdasarkan hasil PKM, kepada peserta PKM disarankan untuk menjadikan perilaku sehat pada saat menggunakan gawai sebagai suatu kebiasaan. Kepada guru/wali murid disarankan untuk mamantau dan mendampingi siswa dalam menggunakan gawai. Dengan demikian diharapkan masalah kesehatan baik fisik maupun mental akibat penggunaan gawai berlebihan pada siswa dapat dicegah.

\section{UCAPAN TERIMA KASIH}

Pengabdi mengucapkan terima kasih kepada Kepala Sekolah SMP Islam Dian Didaktika Bapak Suparjo, S.Pd.Bio., narahubung sekolah Ibu Wahyu Purwaningsih, S.Pd.Si., para guru, dan staf yang banyak membantu sehingga kegiatan PKM ini dapat terlaksana dengan baik. Pengabdi juga berterima kasih kepada Goldi Natanael, mahasiswa Fakultas Kedokteran Universitas Pembangunan Nasional Veteran Jakarta, atas budi baiknya membantu dalam persiapan dan pelaksanaan PKM ini.

\section{DAFTAR PUSTAKA}

[1] Peraturan Pemerintah Republik Indonesia Nomor 21 Tahun 2020 Pasal 4 tentang PSBB.

[2] Keputusan Bersama Kementerian Pendidikan dan Kebudayaan, Kemeterian Agama, Kementerian Kesehatan, dan Kementerian Dalam Negeri Tanggal 15 Juni 2020 tentang Panduan Penyelenggaraan Pembelajara Pada Tahun Ajaran dan Tahun Akademik Baru Di Masa Pandemi Corona Virus Disease (Covid-19).

[3] Kominfo. 2015. Kecanduan Gawai Ancam Anak-anak. https://kominfo.go.id/content/detail/13547/ kecanduan-gawai-ancam-anakanak/0/sorotan_media [Disitasi: 2 Februari 2020]

[4] P. Raraswati . Mendidik Anak di Era Digital.Jakarta: Kementerian Pendidikan dan Kebudayaan; 2016. 
Jurnal Pelayanan dan Pengabdian Masyarakat (PAMAS)

[5] American Academiy of Opthalmology. 2019. Protect Your Eyes From Too Much Screen Time. https://www.aao.org/newsroom/news-releases/detail/protect-your-eyes-from-too-much-screentime [Disitasi: 2 Februari 2020]

[6] Departemen Kesehatan. 2019. Cegah Computer Vision Syndrome dengan Berpostur yang Baik di Depan Komputer. http://www.p2ptm.kemkes.go.id/ infographic-p2ptm/gangguan-indera/cegahcomputer-vision-syndrome-dengan-berpostur-yang-baik-di-depan-komputer [Disitasi: 2 Februari 2020] 